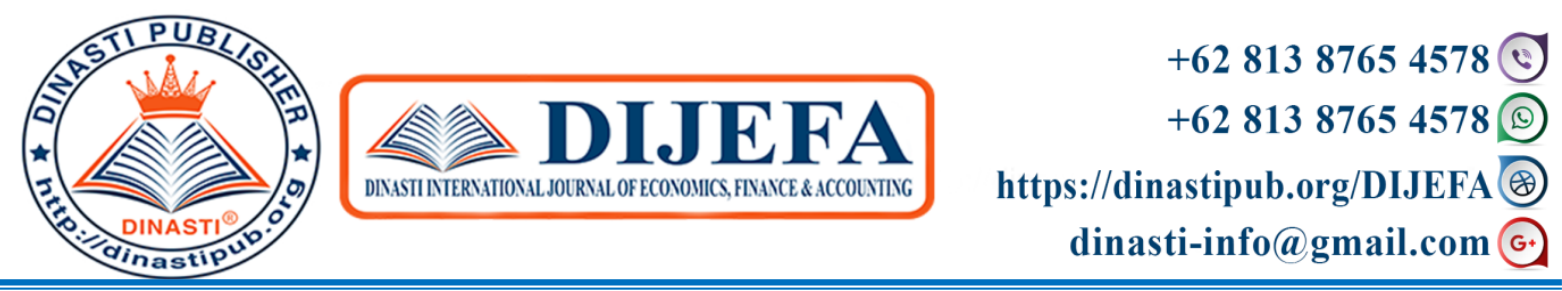

\title{
BUSINESS ANALYSIS OF CANVAS AND SWOT MODELS (CASE STUDY FOR CULINARY CROSSBREED CAKE "TN. XYZ")
}

\section{Victor}

Universitas Mercu Buana, Jakarta, Indonesia

ARTICLE INFORMATION

Received: $21^{\text {st }}$ May 2020

Revised: $20^{\text {th }}$ June 2020

Issued: $19^{\text {th }}$ July 2020

Corresponding author: first author E-mail:

Victor.zoe2786@gmail.com

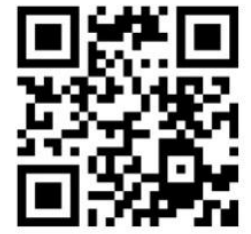

DOI:10.38035/DIJEFA
Abstract: Basket cakes (some call them baskets), named after their printed basket-shaped containers, are cakes made from sticky rice flour and sugar and have a sticky and sticky texture. This cake is one of the typical cakes or mandatory Chinese New Year celebrations. "TN.XYZ" Basket Cake Business is a domestic company that makes basket cakes that are normally made and marketed each year before the Chinese New Year celebrations. The value proposition of "TN.XYZ" Basket Cake is a typical Peranakan cuisine that is marketed before the Chinese New Year. The channel chosen by the owner to verbally sell his products using traditional methods also uses digital technology via social media Instagram. In addition, the owner performs consignment storage in traditional markets and sells products to retail outlets as product demand increases. Customer relationship from Kue Basket "TN.XYZ" via social media Instagram. WhatsApp is also used to upload the results of testimonials from consumers who have already purchased "TN.XYZ" cake basket products through online media.

Keywords: Business model canvas, SWOT analysis, marketing strategy, basket cake, Peranakan Culinary

\section{INTRODUCTION}

The growth of the grocery business shows that business in the food sector is promising. The above phenomenon means that entrepreneurs from the food industry compete with each other to continue making changes so that the company can continue to exist. Producers in this industry try to ensure that business activities that are carried out can be accepted and preferred by consumers.

Basket cake (some call it basket cake), which takes its name from its printed basketshaped container, is a cake made from sticky rice flour and sugar and has a chewy and sticky texture. Basket cake is one of the typical cakes or mandatory Chinese New Year celebrations, 
although not in Beijing all at once. This basket cake is generally used as an offering during the ancestral prayer ceremony seven days before the Chinese New Year and culminating on the eve of the Chinese New Year. As an offering, this cake is usually only eaten at Cap Go Meh (15th night after the Chinese New Year). Basket cakes are made in many cities, including Tangerang, Bogor, Sukabumi and Jogyakarta.

Peranakan culinary cake basket "Tn.XYZ" is one of the domestic industries that is still applicable based on the modern era. The home business he made is Kue Basket, one of the typical snacks from the culture of the Tinghoa community in Indonesia. The business that is run is still in the traditional phase, initially based only on word-of-mouth marketing based on the testimonials and experiences of consumers using these products. Now the family business has entered the second generation phase, although this company can be described as seasonal, meaning it only exists 45 days before and after the Chinese New Year, which is celebrated by some of the Indonesian Chinese. Nevertheless, this paganism can be enjoyed to a large extent by all levels of society from different groups, since the shape of the product is very simple and can be used or processed into other products. Traditionally, this basic edible composition is very simple and consists only of water, sticky rice flour, palm sugar and granulated sugar. What makes it different from any manufacturer is the way it is processed and the time it takes to process it.

The formulation of the problem that can be presented in this study is that the author identifies and evaluates the business model that will be applied to the culinary business of Peranakan Cake Basket and creates a new business model based on the Business Model Canvas- Approach based on Osterwalder and Pigneur (2010). The nine elements of BMC are divided into customer segments, value proposition, channels, customer relationships, sources of income, key resources, key activities, key partnerships and cost structure.

The aim of this research is to analyze the culinary strategy of Peranakan Cake Basket "TN. XYZ" and to reformulate it.

\section{LITERATURE REVIEW}

Alexander Osterwalder and Yves Pigneur have developed a concept that simplifies business concepts that can be used in all industries. The concept is called the business model. The business model is a method or a way to add value (Royan, 2014). According to (Wheelen \& Hunger, 2012), the business model is a method by which companies make money in the current business environment. According to Rappa, the business model is a method that companies use to run their businesses in order to survive. In the mid-nineties, the business model, in line with the development of the Internet as a basis for business according to Demil \& Lecocq in (Wardhana, 2014), became an increasingly popular topic. Based on the definition of the business model proposed by Osterwalder \& Pigneur (2012), which is a fundamental picture of thinking about how companies create, deliver and capture value. This concept can help to describe and think about other organizations, competitors and companies. Osterwalder \& Pigneur (2012: 15) offers nine elements, namely customer segments, value proposition, channels, customer relationships, sources of income, key resources, key activities, key partnerships and cost structures. 
Business Model Canvas (BMC) is the same language for describing, visualizing, evaluating and changing business models (Osterwalder and Pigneur, 2012: 12). To understand how to work in large and complex organizations, you need an image that can help turn the assumptions that cannot be spoken into clear information so that they can be effectively communicated (Clark et al., 2012 : 31). In the Business Model Canvas there are nine sections in which the individual business components are explained: customer segments, value proposition, channels, customer relationships, sources of income, key resources, key activities, key partnerships and cost structures.

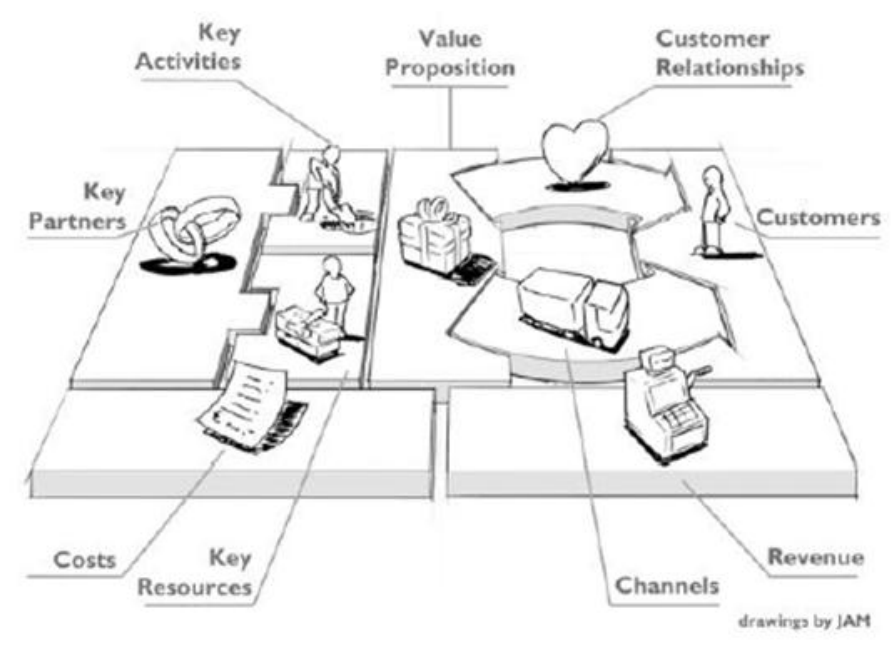

Figure 1. Business Model Canvas (BMC) Source: Osterwalder and Pigneur (2010)

The Canvas Business Model ("BMC") developed by Osterwalder \& Yves Pigneur (2010) is a tool that companies can use to create value. BMC enables entrepreneurs to see how they can run their businesses. This will involve many units in the production process as well as in marketing and other departments. and how companies maintain relationships with their customers so that they can maintain their business. The advantages of BMC are a tool for strategic planning and development. a tool for expressing ideas; a tool for understanding customer segmentation; as a dashboard or indicator tool; a tool to find out how competitors are (like the level of competition). In addition, BMC can also be used as an instrument for analyzing portfolio business models. Innovation planning; and also as an instrument for harmonizing the mindset of individuals in the organization.

BUSINESS APPLICATION OF CANVAS MODELS The business model has the task of organizing, coordinating, visualizing, understanding, communicating and integrating the entire business logic (Osterwalder, 2004). The business model created must be fairly simple, logical, measurable, comprehensive and operationally sensible (Osterwalder et al., 2004). The nine business elements of the canvas business model are as follows:

1. Value proposition is a value that the company positions for potential customers. These values include a product or service and how the company wants to be seen by potential customers. 
2. Customer segment developed A product has to be adapted to the target segmentation of the seven companies. This is done so that the product can be accepted on the market.

3. Channels, channel here shows how companies communicate and reach their customer segments (Osterwalder \& Pigneur 2010).

4. Customer Relationships A new business must be known to potential customers as it is very important to express the business. Customer relationships can be said how the company determines the type of relationship with the customer segment (Osterwalder \& Pigneur 2010) in order to establish good communication. Relationships with customers need to be maintained both offline and online. There are several options, namely discounts and special offers that draw customers' attention, creating better communication with customers and providing email newsletters and applications with various features that customers can use to meet their needs.

5. Sources of income This element is the core of the business model (Osterwalder \& Pigneur 2010). This element shows how sources of income get into the company.

6. Key resources Resources start here with the processing of raw materials, the structuring of human resources and the structuring of business processes. Resources are the most important capital to make a business model work (Osterwalder \& Pigneur 2010).

7. Main Activities The main activities in a business model are now important. This will be the focus of the steps and preparations on which the business will develop. We use this element to describe what companies will do to create functioning business models, such as: B. Production, problem solving, platform activities and networks used (Osterwalder \& Pigneur 2010).

8. Key partnerships Key partnerships are a network of suppliers and partners that make the business model work (Osterwalder \& Pigneur 2010). Partnerships can be a strategic alliance between non-competitors and also competitors, employees, suppliers and everyone involved to develop the company.

9. Cost structure Efficient cost management makes our business more economical and can minimize the risk of loss. This part of the cost structure describes all costs that arise for the operation of the designed business model (Osterwalder \& Pigneur 2010).

\section{SWOT analysis}

According to Kotler and Armstrong (2012: 53-54), the SWOT analysis is a marketing analysis in which strengths, weaknesses, opportunities and risks are assessed.

\section{RESEARCH METHODS}

This research uses quantitative methods, this method is used for several reasons. First, adapting the quantitative method is easier when dealing with multiple realities. Secondly, this method is more sensitive and adaptable to the many sharpenings of mutual influence and to the patterns of the values encountered. The main sources of data in quantitative research are data such as research documents, journal media and others. Data sources indicate the origin of the information received. Data from suitable and relevant sources. The research method used in this research is a descriptive qualitative research method. Descriptive research was 
carried out to explain the properties of various research variables in certain situations. This research can also be called research that explains the phenomenon as it is, Ali (2013).

\section{FINDINGS AND DISCUSSION}

"TN.XYZ" Cake Basket Peranakan Culinary Business is a family business that is run down. The products produced are cake baskets, special foods, which are served before the Lunar New Year (Lunar) celebration. Based on the data collection and reduction of the interviews, results were found that map the culinary business process of Peranakan Cake Basket "TN". XYZ "on nine business models for canvas models.

Table 1. Culinary Business Process

\begin{tabular}{|c|c|c|c|c|}
\hline Key Partner & Key Activities & Value Proposition & $\begin{array}{c}\text { Customer } \\
\text { Relationship }\end{array}$ & $\begin{array}{l}\text { Customer } \\
\text { Segment }\end{array}$ \\
\hline $\begin{array}{l}\text { - Raw Material } \\
\text { Suppliers (Granulated } \\
\text { Sugar, Palm Sugar, } \\
\text { Glutinous Rice Flour) }\end{array}$ & \begin{tabular}{|l} 
- Basket Cake \\
Sales \\
- Join the event \\
every Chinese \\
New Year \\
(Chinnesse \\
Lunar NewYear) \\
\\
- Control the \\
Production \\
Process \\
optimally \\
Key Resources \\
\\
\\
\\
\\
- Human \\
Resources \\
- Equipment \\
and Supplies \\
- Hereditary \\
recipes \\
- Means of \\
transportation; 3 \\
wheel \\
motorcycle \\
- \\
Communication \\
tool; Android- \\
based device
\end{tabular} & $\begin{array}{l}\text { - Typical } \\
\text { Peranakan Cuisine } \\
\text { - Traditional } \\
\text { traditional snacks } \\
\text { are treated every } \\
\text { Chinese New Year } \\
\\
\text { - Can be } \\
\text { consumed for a } \\
\text { period of } 3-4 \\
\text { months } \\
\text { - Can be } \\
\text { processed into } \\
\text { dishes in other } \\
\text { forms (Steamed, } \\
\text { Fried, Made } \\
\text { Pudding) }\end{array}$ & \begin{tabular}{|l|} 
- brochure \\
- Radio \\
advertising; Online \\
Retail (Tokped, \\
Blibli, Shopee, \\
Bukalapak) \\
- Social Media \\
(Youtube, \\
Instagram, FB, \\
Twitter) \\
Channels \\
\\
- Social Media \\
- Retail
\end{tabular} & $\begin{array}{l}\text { - Geographic: } \\
\text { JABODETABEK } \\
\text { (Jakarta, Bogor, } \\
\text { Depok, Tangerang, } \\
\text { Bekasi) } \\
\text { - Demographics: } \\
\text { All Ages, Women } \\
\text { and Men } \\
\text { - Psychological: } \\
\text { Asper heritage of } \\
\text { cultural traditions } \\
\text { and parts of the } \\
\text { culinary } \\
\text { archipelago }\end{array}$ \\
\hline \multicolumn{2}{|c|}{ Cost Structure } & \multicolumn{3}{|c|}{ Revenue Stream } \\
\hline \multicolumn{2}{|c|}{$\begin{array}{l}\text { - Cost of Purchasing } \\
\text { - cost Equipment } \\
\text { - Transportation Expences } \\
\text { - Operasional Expences }\end{array}$} & \multicolumn{3}{|c|}{ - Revenue from Sales } \\
\hline
\end{tabular}

Gambar 2.BUSINESS ANALYSIS OF CANVAS CULINARY CROSSBREED CAKES "TN. XYZ"

\section{a. Customer Segment}

Geographic aspects of TN Basket Cake. XYZ is a municipality that lives in the JABODETABEK region (DKI Jakarta, Bogor, Depok, Tangerang and Bekasi). Demographic aspects to be considered by the participant "Basket Cake". XYZ "is the general public who likes Dodol-type food preparations that can be given in multiple circles. In terms of age, it can range from teenagers to parents. But it excludes the possibility of children or the elderly as well as this culinary not because the price is fairly affordable and the taste is unique and distinctive, and finally the psychographic aspects that the basket cake "TN" Events can be enjoyed every year, during the upcoming Chinese New Year (Lunar), so this meal can become a mandatory meal for certain groups of people that must always be missed and enjoyed. 
b. Value proposition

After knowing the customer or consumer groups interested in basket cake, the author focuses on the value that basket cake "TN.XYZ" offers, a type of dodol food that tastes sweet and has a soft and unique texture .

c. channels

Steps to find out how to ask Basket Cake "TN. XYZ" is purchased by customers and needed by channels. "TN. Owner of a basket cake business. XYZ "uses several channels to convey its value proposition, namely to reach its customers by selling products online via social media such as Instagram, Youtube, FB, WhatsApp and distributing brochures as a channel for the sale of products to consumers. In addition, basket cake "TN. XYZ" is also sold by handing it over to traditional markets, grocery stores that are sold through retail channels.

d. Customer relationship

Basket cake "TN. XYZ" creates relationships with consumers through advertising in a traditional way, ie word of mouth, based on the testimony of consumers who are satisfied and satisfied with the product they have bought because it is delivered correctly and on time. After the era of digital technology development, the basket cake business "TN XYZ" is also marketed by his little son, who is the next successor of this business, via Instagram, WhatsApp, FB. Also used to upload the results of testimonials from consumers who have already purchased Cake Basket products made through WhatsApp media. Customers are asked for satisfaction from service to product taste. In addition, basket cake "TN. XYZ" also uses brochures that are distributed in traditional markets to build relationships with consumers. Using the brochure will provide you with information about the product that is expected to be an attraction for consumers to buy.

e. . Revenue Stream

The main source of income for Kue Basket "TN. XYZ" is obtained only from the sale of basket cake products, the income from sales activities. Entrepreneurs always maximize sales levels to generate revenue in line with goals.

f. Key resource

The most important resource of Kue Basket "TN. XYZ" is a human resources department, which consists of employees who help the production / processing department and at the same time become couriers. To maximize human resource performance, business owners typically select their employees who are relatives or neighbors who are known to be close to the owner so that trust in the production process remains consistent. In addition, no less important resources are the equipment and equipment needed for the production process of this business. Communication tools such as cell phones and three-wheeled motorcycles (Viar) are also required. Mobile phones and motorcycles are expected to maximize the business continuity process. The recipe for hereditary inheritance as well as the type of processing and the process of processing, which can be the distinguishing feature between "TN-made basket cakes", is no less important. XYZ "with other brands, because interviews with the owner of the material used simply require sticky rice flour, granulated sugar, palm sugar and water, but the difference is the manufacturing process, the manufacturing time and the manufacturing stages. 


\section{g. Key activities}

The main activity to achieve the TN Basket Cake business sales target. XYZ "is through basket cake sale. Basket Cake" TN. XYZ "will sell basket cakes taking into account the quality from the raw materials to the packaging process. Furthermore, the key activity of Kue Basket" TN. XYZ "is preparing to start production at the right time before the Chinese New Year, which will occur every year, including by following the food bazaar. Maximum control of the production and marketing processes is also part of the main activities of the owner.

h. Key partner

Basket cake "TN. XYZ" works with different parties that contribute to the sustainability of the production process. The main partner of Kue Basket "TN. XYZ" is a raw material supplier in the form of sticky rice of good quality, which is not stored for long, clean palm sugar supplier, palm sugar supplier that produces quality products.

i. Cost structure

Costs incurred Basket Cake "TN. XYZ" for running his business are the cost of purchasing raw materials, equipment and equipment costs, endorsement fees, advertising costs, transportation costs, operating costs and salary costs.

Table 2. Financial Aspects of Basket Cake "TN. XYZ "

\begin{tabular}{|c|c|c|c|}
\hline Name of goods & Unit & Price/unit (IDR) & TOTAL (IDR) \\
\hline Machine Steamer 20 & & & \\
\hline Tray & 1,00 & $27.000 .000,00$ & $27.000 .000,00$ \\
\hline Sodet & 2,00 & $25.000,00$ & $50.000,00$ \\
\hline Plastic Mold & 100,00 & $15.000,00$ & $1.500 .000,00$ \\
\hline Filter & 10,00 & $25.000,00$ & $250.000,00$ \\
\hline Big spoon & 10,00 & $10.000,00$ & $100.000,00$ \\
\hline Knife & 4,00 & $25.000,00$ & $100.000,00$ \\
\hline Scale & 2,00 & $80.000,00$ & $160.000,00$ \\
\hline The kitchen table & 3,00 & $300.000,00$ & $900.000,00$ \\
\hline The kitchen Chair & 3,00 & $90.000,00$ & $270.000,00$ \\
\hline Vehicle (Motorcycle) - & & & \\
\hline VIAR & 1,00 & $31.000 .000,00$ & $31.000 .000,00$ \\
\hline Handphone & 1,00 & $2.500 .000,00$ & $2.500 .000,00$ \\
\hline \multicolumn{3}{|c|}{ Req Fund for Fixes Assets } & $63.830 .000,00$ \\
\hline \multicolumn{4}{|l|}{ Working Capital } \\
\hline \multicolumn{3}{|l|}{ Cash Reserves } & $20.000 .000,00$ \\
\hline \multicolumn{3}{|l|}{ Raw Material Costs } & $260.500 .000,00$ \\
\hline \multicolumn{3}{|l|}{ Employee Salary Costs } & $6.000 .000,00$ \\
\hline \multicolumn{3}{|l|}{ Equipment Costs } & $1.500 .000,00$ \\
\hline \multicolumn{3}{|l|}{ Electricity cost } & $500.000,00$ \\
\hline \multicolumn{3}{|l|}{ Water cost } & $1.000 .000,00$ \\
\hline \multicolumn{3}{|l|}{ Gas Cost } & $2.000 .000,00$ \\
\hline \multicolumn{3}{|l|}{ Credit Fee } & $200.000,00$ \\
\hline \multicolumn{3}{|l|}{ Brochure Printing Fee } & $200.000,00$ \\
\hline \multicolumn{3}{|l|}{ Advertising Costs } & $500.000,00$ \\
\hline \multicolumn{3}{|l|}{ Additional costs } & $470.000,00$ \\
\hline \multicolumn{3}{|l|}{ Endorsement fee } & $500.000,00$ \\
\hline \multicolumn{3}{|l|}{ WORKING CAPITAL } & $293.370 .000,00$ \\
\hline \multicolumn{3}{|l|}{ TOTAL FUNDS REQ. } & $357.200 .000,00$ \\
\hline
\end{tabular}

Based on the table above, the TN Basket Cake. XYZ "for the purchase of fixed assets and for the financing of working capital in a production process per year in the amount IDR $357,200,000$. 
Table 3. Profit and Loss Projection

Profit \& Loss Projection 2019 Basket Cakes "TN. XYZ"

\begin{tabular}{|c|c|c|}
\hline Revenue & & $325.000 .000,00$ \\
\hline \multicolumn{3}{|l|}{ COGS } \\
\hline Raw Material Costs & $260.500 .000,00$ & \\
\hline Employee Salary Costs & $6.000 .000,00$ & \\
\hline Electricity cost & $500.000,00$ & \\
\hline Water cost & $1.000 .000,00$ & \\
\hline Gas Cost & $2.000 .000,00$ & \\
\hline TOTAL COGS & & $270.000 .000,00$ \\
\hline GROSS PROFIT & & $55.000 .000,00$ \\
\hline \multicolumn{3}{|l|}{ OPERATIONAL } \\
\hline \multicolumn{3}{|l|}{ EXPENCES } \\
\hline Endorsement fee & $500.000,00$ & \\
\hline Equipment Costs & $1.500 .000,00$ & \\
\hline Credit Fee & $200.000,00$ & \\
\hline Advertising Costs & $500.000,00$ & \\
\hline Brochure Printing Fee & $200.000,00$ & \\
\hline Additional costs & $470.000,00$ & \\
\hline Depretiation & $15.957 .500,00$ & \\
\hline \multicolumn{3}{|l|}{ TOTAL OPERATIONAL } \\
\hline EXPENCES & & $19.327 .500,00$ \\
\hline EARNING BEFORE TAX & & $35.672 .500,00$ \\
\hline Income Tax $1 \%$ & & $3.250 .000,00$ \\
\hline \multicolumn{3}{|l|}{ EARNING AFTER TAX / } \\
\hline NET PROFIT & & $32.422 .500,00$ \\
\hline
\end{tabular}

Based on the data in the table above for the projection of the profit and loss of "TN.XYZ" basket cake, the profit before tax received by the owner in 2019 was IDR 35,672,500.00. After deduction of $1 \%$ of the tax of the net sales, the net profit generated by the owner was IDR 32,422,500.00. 
Table 4. Balance Sheet

\begin{tabular}{|c|c|c|}
\hline \multicolumn{3}{|l|}{ AS OF 31 DES 2019} \\
\hline \multicolumn{3}{|l|}{ Aset } \\
\hline \multicolumn{3}{|l|}{ Current assets } \\
\hline CASH / BANK & & $345.000 .000,00$ \\
\hline \multicolumn{3}{|l|}{ TOTAL CURRENT } \\
\hline ASSETS & & $345.000 .000,00$ \\
\hline \multicolumn{3}{|l|}{ FIXED ASSETS } \\
\hline \multicolumn{3}{|l|}{ Vehicles and mobile } \\
\hline phones & $33.500 .000,00$ & \\
\hline \multicolumn{3}{|l|}{ Accumulated } \\
\hline \multirow{2}{*}{\multicolumn{3}{|c|}{$\begin{array}{l}\text { Depreciation of } \\
\text { vehicles and mobile }\end{array}$}} \\
\hline & & \\
\hline phones & $-8.375 .000,00$ & \\
\hline Kitchen equipment & $30.330 .000,00$ & \\
\hline \multicolumn{3}{|l|}{ Accumulated } \\
\hline \multicolumn{3}{|l|}{ Depreciation of kitchen } \\
\hline equipment & $-7.582 .500,00$ & \\
\hline Total Fixed Assets & & $47.872 .500,00$ \\
\hline TOTAL ASSETS & & $392.872 .500,00$ \\
\hline \multicolumn{3}{|l|}{ Liabilities and Equity } \\
\hline \multicolumn{3}{|l|}{ Current Liabilities } \\
\hline Tax debt & & $3.250 .000,00$ \\
\hline \multicolumn{3}{|l|}{ Total Current } \\
\hline Obligations & & $3.250 .000,00$ \\
\hline \multicolumn{3}{|l|}{ Equity } \\
\hline Owners capital & & $357.200 .000,00$ \\
\hline EARNING 2019 & & $32.422 .500,00$ \\
\hline TOTAL EQUITY & & $389.622 .500,00$ \\
\hline \multicolumn{3}{|l|}{ Total Liabilities and } \\
\hline Equity & & $392.872 .500,00$ \\
\hline
\end{tabular}

Table 4 above shows that by the end of 2019 the total share of the TN.XYZ basket cake business was Rp 392,872,500 at the end of 2019. Based on the above description, the SWOT analysis of the cake basket business "TN.XYZ" is also carried out as follows: 


\section{INTERNAL SWOT FACTORS}

\section{STREGHT}

- Original recipes for generations

- Loyal customer base for culinary basket cake

- $100 \%$ Indonesian original products

- More than 15 years of experience in the production of basket cakes

- The product quality is guaranteed

\section{WEAKNESS}

- Product distribution is somewhat slow due to shipping fleet constraints

- Requires significant capital for the home industry

- home industry

- Limited sales force to reach the retail market

- Less product advertising

\section{EXTERNAL FACTOR SWOTS}

\section{OPPORTUNITY}

- Share of major culinary domestic markets specializing in basket cake

- Small local producer competitors

- People will not be forgotten because it is closely related to culture

- Can enter the modern retail market

\section{TO TREAT}

- Many similar products are managed professionally

- Competitive product prices are cheaper because they are managed on a large scale

- Distribution network Distribution of competitors directly to end users

- New competitors

- Supplier support to limit domestic raw materials

\section{CONCLUSION}

"TN.XYZ" Basket Cake Business is a domestic company that makes basket cakes that are normally made and marketed each year before the Chinese New Year celebrations. The value proposition of "TN.XYZ" Basket Cake is a typical Peranakan cuisine that is marketed before the Chinese New Year. The channel chosen by the owner to verbally sell his products using traditional methods also uses digital technology via social media Instagram. In addition, the owner performs consignment storage in traditional markets and sells products to retail outlets as product demand increases. Customer relationship from Kue Basket "TN.XYZ" via social media Instagram. WhatsApp is also used to upload the results of testimonials from consumers who have already purchased "TN.XYZ" cake basket products that are conducted through online media. Customers are asked for satisfaction from service to product taste. The 
owner also uses brochures to build relationships with consumers. By using the brochure, the owner will provide information about the product that is expected to be an attraction for consumers to buy.improvement.

\section{REFERENCE}

- Ali, Hapzi. 2020. Modul Strategic Management Program Studi Magister Management. UMB Jakarta

- Ali, H., Butarbutar, B. (2019). Analisis SWOT Dalam Menentukan Strategi Pemasaran Produk Jus Bawang Putih Dr Juice 5 In 1 (Studi Kasus: CV. Dewi Rejeki Jakarta). Jurnal Ilmiah Manajemen.

- Kotler, P., Keller K.L. (2008). Manajemen Pemasaran Edisi 13, Jakarta : Penerbit Erlangga.

- Rangkuti, F. (2009). Strategi Promosi yang Kreatif dan Analisis Kasus Integrated Marketing Communication. Jakarta: PT Gramedia Pustaka Utama.

- Osterwalder, Alexander \& Pigneur, Yves. (2010). Business Model Generation. Jakarta: Elex Media Kumputindo.

- Royan, F. M. (2014). Bisnis Model Kanvas Distributor.Jakarta: PT Gramedia Pustaka Utama

- Wardhana, A. (2014). Business Model Canvas.Bandung: PT Karyamanunggal Lithomas

- Wheelen, T. L., \& Hunger, J. D. (2012). Strategic Management and Business Policy(Vol. 13). United States, America: Pearson Education. 